\title{
Molecular detection of Marek's disease virus in feather and blood samples from young laying hens in Colombia
}

\author{
S. LÓPEZ-OSORIO ${ }^{1}$, D. VILLAR², D. PIEDRAHITA², G. RAMÍREZ-NIETO ${ }^{3}$, \\ V. NAIR ${ }^{4}$, S. BAIGENT ${ }^{4}$, J. CHAPARRO-GUTIÉRREZ ${ }^{*}$
}

\begin{abstract}
${ }^{1}$ Centauro Research Group, Faculty of Agrarian Sciences, University of Antioquia, Carrera 75 \# 65-87 (47-241) Medellín, Colombia; ${ }^{2}$ CIBAV Research group. Faculty of Agrarian Sciences, University of Antioquia, Calle 70 No. 52-21, Medellín, Colombia; ${ }^{3}$ Research Group in Microbiology and Epidemiology, Universidad Nacional de Colombia, Bogotá, Colombia, Carrera $45 \mathrm{~N}^{\circ}$ 26-85 - Edificio Uriel Gutiérrez, Bogotá D.C., Colombia; ${ }^{4}$ Avian Oncogenic Virus Group, The Pirbright Institute, Ash Rd, Pirbright, Woking GU24 0NF, UK
\end{abstract}

Summary. - Marek's disease virus (MDV) is an immunosuppressive pathogen that can cause low production efficiency and high mortality rates in chickens. There is no current information on the MDV serotypes and pathotypes circulating in vaccinated commercial farms in Colombia where the birds are vaccinated in the incubator with Gallid herpesvirus (GaHV-2) and Meleagrid herpesvirus 1 (MeHV-1). Based on that, the main focus of this study was to understand the MDV's infection dynamics for the three known serotypes and to detect wild-virus pathogenic strains in 4-layer poultry farms in Antioquia. Samples of blood, feathers and spleens were collected from three randomly chosen animals according to age category: 1, 15, 30, 60, 90, and 120 days. Quantitative real-time PCR (qPCR) that differentiates between the three serotypes of MDV was used to assess viral loads over time, and phylogenetic analysis of the Meq oncogene was done to compare the strains of MDV with those of known pathogenicity. Meleagrid herpesvirus 1 (MeHV-1) was detected in all blood and feather follicle samples with an average number of genome copies (per 10,000 cells) of 31.44 in blood as expected as a result of vaccination. GaHV-2 was also detected in almost $100 \%$ of the blood and feather follicle samples throughout all defined age categories, with an average of 10.65 genome copies in blood samples. Gallid herpesvirus 3 (GaHV-3) was detected in $72 \%$ of blood and $84.61 \%$ of feather samples, with less than 1 copy per 10,000 cells. Based on the number of $132 \mathrm{bp}$ repeats of the BamHI-H and BamHI-D regions in pooled feather samples, there were $70 \%$ (8/25) of attenuated MDV and 30\% (17/25) of virulent MDV strains circulating in the farms. Virus isolation was performed successfully from every farm. In conclusion, different strains of MDV are circulating for up to 120 days in layers in Antioquia-Colombia and could be of major impact in poultry health.

Keywords: Marek's disease virus (MDV); Antioquia-Colombia; qPCR; PCR; Meq gene phylogeny

\section{Introduction}

Infection with GaHV-2 (Gallid herpesvirus 2), an Alphaherpesvirus of the genus Mardivirus and etiologic

*Corresponding author. E-mail: jenny.chaparrog@udea.edu.co; phone: +5742199122 .

Abbreviations: $\mathrm{CPE}=$ cytopathic effect; $\mathrm{CEF}=$ chicken embryo fibroblast; GaHV-2, -3 = Gallid herpesvirus 2, 3; MD = Marek's disease; $\mathrm{MDV}=$ Marek's disease virus; MeHV-1 = Meleagrid herpesvirus 1 agent for Marek's disease (MD), is the most ubiquitous avian infection in chicken flocks occurring worldwide. Two other members of the genus that are non-pathogenic and commonly used as vaccine are GaHV-3 (Gallid herpesvirus 3) and MeHV-1 (Meleagrid herpesvirus 1) (Afonso et al., 2001). Although current vaccines greatly reduce clinical disease, they do not prevent infection and shedding of Marek's disease virus (MDV) in the vaccinated host. In fact, the use of "leaky" vaccines over the past decades has created the ideal conditions to allow transmission and evolution of wild-type pathogenic strains, even in the presence 
of vaccination (Read et al., 2015). Some of these new and highly virulent MDV isolates ( $\mathrm{vv}$ and $\mathrm{vv}+\mathrm{MDV}$ strains) are causing sporadic outbreaks of $\mathrm{MD}$, overcoming vaccination protection (Zhang et al., 2015; Lopez-Osorio et al., 2017; López et al., 2015), and can now lead to clinical signs and high mortality rates as early as 8-14 days post-infection, particularly in non-vaccinated chickens free of maternal antibodies (Gimeno, 2008).

The epidemiological situation of MDV in Colombia is unknown, and although clinical disease is not always apparent, every flock is presumed to be infected. In fact, some producers claim economic losses due to decreased growth rates and egg production, condemnations at slaughter, and uneven flocks that could be attributed to MDV infection. We recently documented an outbreak of MD due to a highly virulent $(\mathrm{vv}+)$ isolate of MDV in a layer chicken farm with an overall mortality rate of $37.7 \%$. This is troublesome since the farm was already using the most effective attenuated GaHV2 strain vaccine (CVI988/Rispens), which currently is the last line of defense, developed against the most pathogenic strains of MDV (Lopez-Osorio et al., 2017).

According to the Colombian Institute of Agriculture (Instituto Colombiano Agropecuario, ICA) in its resolution 811 of 1992, all commercial broiler and layer chickens had to be vaccinated at one day of age. More recent regulations starting 2014, also establish the requirements for the sanitary registration of poultry farms and biosecurity certification, and make vaccination against MDV mandatory either at day 18 of incubation (in ovo) or at day 1 of age (subcutaneous). Currently, there are more than 45 commercially available vaccines registered in Colombia with one or combinations of the three serotypes of MDV. In spite of that, a recent outbreak was reported on a layer flock in which the day-old chicks had been vaccinated with MeHV-1 strain FC126 and GaHV-2 Rispens strain (Lopez-Osorio et al., 2017). Whether improper vaccination technique or a vaccine failure took place was unknown. However, previous studies in which a vV+ MDV was identified and the evolution of MDV was examined, would point to a breach in vaccine immunity in this case.

The diagnosis of MD is based on a combination of necropsy and histopathology findings, along with viral DNA analysis and confirmation by in vitro viral isolation (Schat and Nair, 2013; Ramírez et al., 2010). Having the genomes for all three serotypes of MDV completely sequenced, techniques like the real-time quantitative PCR (qPCR) can now quantify viral loads in tissues and enable differentiation between oncogenic and non-oncogenic strains of serotype $1 \mathrm{MDV}$, in addition to those of the other two serotypes (Baigent et al., 2005, 2011, 2016; Renz et al., 2006; Islam et al., 2006). The standard PCR is another diagnostic tool that can be used to identify infected birds, and help to determine viral pathotypes within a flock at any given time (Davidson and Borenshtain, 2002). From a practical point of view, the simultaneous quantification and comparison of the vaccine and field virus strains in poultry can help to determine the efficacy of a given vaccine (Baigent et al., 2011), and better characterize outbreaks of MD due to vaccine failures (Landman and Verschuren, 2003).

It is known that birds vaccinated with CVI988 and then challenged with very virulent strains of MDV will have reduced viremia and shed fewer virus particles in feather follicles at various days post-infection compared with unvaccinated birds (Haq et al., 2012). This inhibitory influence of some vaccines on the replication of virulent wild-type strains of MDV in the host is important to reduce transmission and so could potentially be used as a proof of vaccine success (Islam et al., 2014). In addition, apart from determining MDV-antibody titers, the establishment of high vaccinespecific (Rispens/CVI988 and HVT) viral loads in a high percentage of feather samples can also be used as an indicator of vaccination success (Ralapanawe et al., 2016). Based on this, in the present study, we used specific real-time qPCR to determine persistence of the vaccinal Rispens and MeHV-1 (FC126 HVT) infection and the extent of co-infection with wild-type MD virus in vaccinated layers.

\section{Materials and Methods}

Sample collection. Whole blood, spleen and feather samples were collected from 72 birds from four different commercial farms in Antioquia-Colombia (eastern and northern regions), where chickens had been vaccinated with the FC126 HVT and CVI988Rispens bivalent vaccine at one-day of age. Although neither farm had previous history of $\mathrm{MD}$, the producers complained of poor performance, frequent bacterial infections and higher mortality rates than previous years. In each of the farms, blood, spleen and feather samples were taken from three birds in each of six different age groups (1-, 15-, 30-, 60-, 90- and 120-day-old). Day 1 was considered as the first day at farm, about 2 days after hatch and having received the vaccines. The chickens sampled were young layers (ISA Brown and Hy-line Brown) that did not show clinical signs. In parallel, samples were taken from 10 backyard birds in nearby farms, which were not vaccinated. At each sampling point, the three birds were euthanized by cervical dislocation and sampled as follows: spleens were frozen at $-80^{\circ} \mathrm{C}$ for virus isolation, and blood and feather samples were preserved at $-20^{\circ} \mathrm{C}$ until processing for DNA extraction (Bagust, 2008; FAO, 2006).

DNA extraction. The feather samples were pooled by age and farm (5 feathers per animal, 15 per age). For DNA extraction, feather tips were cut with sterile scalpel blades at approximately $5 \mathrm{~mm}$ thickness. These fragments were subsequently placed in sterile $2 \mathrm{ml}$ microcentrifuge tubes and $180 \mu \mathrm{l}$ of ATL buffer plus $20 \mu \mathrm{l}$ of proteinase $\mathrm{K}$ were added. The mixture was macerated and incubated for $1 \mathrm{~h}$ at $56^{\circ} \mathrm{C}$ with vigorous vortexing every $15 \mathrm{~min}$. 
Table 1. Set of primers for conventional PCR

\begin{tabular}{|c|c|c|c|}
\hline Target & Primer sequence $5^{\prime}-3^{\prime}$ & Product length & Reference \\
\hline $\begin{array}{l}\text { GaHV-2 } \\
\text { gene }(\mathrm{Meq})\end{array}$ & $\begin{array}{l}\text { 5'-ATGTCTCAGGAGCCAGAGCCGGCGCT-3' } \\
\text { 5'-GGGGCATAGACGATGTGCTGCTGAG-3' }\end{array}$ & 1062 bp & Lee et al., 2000 \\
\hline $\begin{array}{l}\text { GaHV-2 } \\
\text { gene }(M e q 2) \text { (sequencing) }\end{array}$ & $\begin{array}{l}\text { 5'-CCGCACACTGATTCCTAGGC-3' } \\
\text { 5'-AGAAACATGGGGCATAGACG-3' }\end{array}$ & $\begin{array}{l}1148 \text { bp (RB1B) } \\
1325 \text { bp (Rispens) }\end{array}$ & \\
\hline $\begin{array}{l}\text { GaHV-3 } \\
g B B 1-B 2\end{array}$ & $\begin{array}{l}\text { 5'-AACCGTGATCCGTCTAGAACC-3' } \\
\text { 5'-GTTACGCTTGACTGGAAGGC-3' }\end{array}$ & $669 \mathrm{bp}$ & Cho et al., 1998 \\
\hline $\begin{array}{l}\text { MeHV-1 } \\
\text { sorf } 1 \text { gene }\end{array}$ & $\begin{array}{l}\text { 5'-AAGCGCTTGTATGTGTAGG-3' } \\
\text { 5'-TATGGACGTCATGCAGTTGG-3' }\end{array}$ & $350 \mathrm{bp}$ & Islam et al., 2006 \\
\hline $\begin{array}{l}\text { BamHI-H } \\
\text { BamHI-D pathotype }\end{array}$ & $\begin{array}{l}\text { 5'-TACTTCCTATATAGATTGAGACGT-3' } \\
\text { 5'-GAGATCCTCGTAAGGTGTAATATA-3' }\end{array}$ & $434 \mathrm{bp}$ & Becker et al., 1993 \\
\hline $\begin{array}{l}\mathrm{H} 3-\mathrm{H} 8 \\
\text { reference gene }\end{array}$ & $\begin{array}{l}\text { 5'-AACAACACCGATTTAGCCAGC-3' } \\
\text { 5'-TGGTGAATCCACAATATCTACGAC-3' }\end{array}$ & $360 \mathrm{bp}$ & \\
\hline
\end{tabular}

Table 2. Primers and probes used in $\mathrm{qPCR}$

\begin{tabular}{|c|c|c|c|c|}
\hline Target/Name & Direction & Primer sequence $5^{\prime}-3^{\prime}$ & Product length & Reference \\
\hline \multirow{3}{*}{$\begin{array}{l}\text { GaHV-2 } \\
\text { Meq gene } \\
\text { qPCR }\end{array}$} & Forward & GGT CTG GTG GTT TCC AGG TGA & $73 \mathrm{bp}$ & Sellers, 2001 \\
\hline & Reverse & GCA TAG ACG ATG TGC TGC TGA & & Jones et al., 1992 \\
\hline & probe & $\begin{array}{l}\text { AGA CCC TGA TGA TCC GCA TTG CGA CT } \\
\left(5^{\prime} \mathrm{FAM}, 3^{\prime} \mathrm{BHQ} 1\right)\end{array}$ & & \\
\hline \multirow{3}{*}{$\begin{array}{l}\text { GaHV-3 (MDV-2) } \\
\text { DNA pol gene } \\
\text { qPCR }\end{array}$} & Forward & AGC ATG CGG GAA GAA AAG AG & $100 \mathrm{bp}$ & Islam et al., 2004 \\
\hline & Reverse & GAA AGG TTT TCC GCT CCC ATA & & \\
\hline & probe & CGC CCG TAA TGC ACC CGT GAC T & & \\
\hline \multirow{3}{*}{$\begin{array}{l}\text { MeHV-1 (HVT) } \\
\text { sORF1 gene } \\
\text { qPCR }\end{array}$} & Forward & GGC AGA CAC CGC GTT GTA T & $77 \mathrm{bp}$ & Islam et al., 2004 \\
\hline & Reverse & TGT CCA CGC TCG AGA CTA TCC & & \\
\hline & probe & AAC CCG GGC TTG TGG ACG TCT TTC & & \\
\hline \multirow{3}{*}{$\begin{array}{l}\text { Chicken / Ovotrans- } \\
\text { ferrin (OT) gene } \\
\text { control } \\
\text { qPCR }\end{array}$} & Forward & CAC TGC CAC TGG GCT CTG T & $71 \mathrm{bp}$ & Jeltsch et al., 1987 \\
\hline & Reverse & GCA ATG GCA ATA AAC CTC CAA & & \\
\hline & probe & $\begin{array}{l}\text { AGT CTG GAG AAG TCT GTG CAG CCT CCA } \\
\text { (5'Yakima Yellow, 3'TAMRA) }\end{array}$ & & \\
\hline
\end{tabular}

Primers and probes Sigma. YY TAMRA probe from Eurogentec.

DNA extraction was performed using the Qiagen DNA extraction kit (Qiagen, Netherlands) based on the manufacturer's instructions and as previously described (Baigent et al., 2005; Bello et al., 2001; Renz et al., 2006; Abdul-Careem et al., 2006). Whole blood samples were processed according to the manufacturer's protocol using a Blood and tissue kit (QIAamp, Qiagen). Total DNA concentration was quantified using a Nanodrop ND-1000 UV-vis spectrophotometer (NanoDrop Technologies, USA).

Conventional MDV PCR. Sets of specific oligonucleotide primers (GaHV-2 gene Meq, GaHV-3 gB B1-B2, MeHV-1 sorf 1 gene, Table 1) were used to detect each of the MDV serotypes. PCR conditions were optimized in a $50 \mu \mathrm{l}$ reaction volume; $2.5 \mathrm{U}$ of Taq polymerase (Invitrogen, USA), $4 \mathrm{mM}$ of $\mathrm{MgCl}_{2}, 400 \mathrm{mM}$ of dNTPs, $1 \mathrm{mM}$ of forward and reverse primer and $10 \mathrm{ng}$ of DNA. Amplification of MeHV-1 was performed using 30 cycles of $94^{\circ} \mathrm{C}$ for $1.5 \mathrm{~min}, 60^{\circ} \mathrm{C}$ for $1 \mathrm{~min}$, and $72^{\circ} \mathrm{C}$ for $2 \mathrm{~min}$. Amplification of GaHV-3 was performed using 35 cycles of $94^{\circ} \mathrm{C}$ for $1.5 \mathrm{~min}$, $55^{\circ} \mathrm{C}$ for $1 \mathrm{~min}$, and $72^{\circ} \mathrm{C}$ for $2 \mathrm{~min}$. For GaHV-2, the amplification was performed using 35 cycles of $94^{\circ} \mathrm{C}$ for $1.5 \mathrm{~min}, 57^{\circ} \mathrm{C}$ for $1 \mathrm{~min}$, and $72^{\circ} \mathrm{C}$ for $2 \mathrm{~min}$. PCR products were separated on a $1 \%$ agarose gel and stained with ethidium bromide $(1 \mathrm{mg} / \mathrm{ml})$. The bands were visualized in a UV trans-illuminator and analyzed using the Gel capture image acquisition software (Bio Imaging Systems, Ireland).

Transportation of samples on FTA cards. $50 \mu \mathrm{l}$ of each DNA of all samples previously prepared were applied onto FTA TM cards (Microcard, Germany) and sent to the Avian Oncogenic Virus Laboratory at the Pirbright Institute (United Kingdom) for analysis by real-time qPCR.

DNA extraction from FTA cards. A rectangle $(1 \mathrm{~cm} \mathrm{x} 0.5 \mathrm{~cm})$ was cut in the center of the card with sterile scissors and placed in a sterile $1.5 \mathrm{ml}$ tube. $50 \mu \mathrm{l}$ of Buffer AE (elution buffer DNeasy blood and tissue kit, Qiagen) was added directly onto the paper. Samples were incubated for $10 \mathrm{~min}$ at $37^{\circ} \mathrm{C}$ and centrifuged at 
13,000 rpm for $3 \mathrm{~min}$. The FTA paper was removed and then the DNA was purified (in the solution) with the QIAquick PCR purification kit (Qiagen). DNA was stored at $4^{\circ} \mathrm{C}$ until required for analysis. To check quality and quantity of DNA for the PCR, the concentration of the standard reference genes $\mathrm{H} 3$ and $\mathrm{H} 8$ were measured by Nanodrop (Thermo Scientific, USA) (Baigent et al., 2005) (Table 1).

Real-time PCR. Real-time quantitative PCR (qPCR) was used for absolute quantification of MDV viral genomes (Baigent et al., 2005 ) in DNA from blood and feather samples. Primers (GaHV-2 Meq gene, GaHV-3 DNA-pol gene, MeHV-1 sORF1 gene, Ovitransferrin gene) and probes for the three serotypes were used in the reaction and are shown in Table 2. qPCR was performed in a final volume of $25 \mu \mathrm{l}$ per well, containing 1x Master Mix (Absolute Blue low ROX qPCR mix, Fisher, USA), $1 \mathrm{mM} \mathrm{MgCl}_{2}, 0.2 \mathrm{mM}$ of each dATP, dCTP, dGTP and dUTP, $0.65 \mathrm{U}$ Taq DNA polymerase and $0.25 \mathrm{U}$ Uracil N-glycosylase. The primers (reverse and forward) were in a concentration of $0.4 \mu \mathrm{M}$ each, in addition to $0.2 \mu \mathrm{M}$ virus probe (5-carboxyfluorescein (FAM) -fluorescent-tagged probe from Sigma-Genosys Ltd., USA), $0.2 \mu \mathrm{M}$ probe OT (chicken ovotransferrin gene) (Yakima Yellow-fluorescent-tagged probe, Eurogentec, Belgium), $10 \mu \mathrm{g}$ Bovine serum albumin (BSA, Sigma, $1.6 \mathrm{mg} / \mathrm{ml}$ ) and $4 \mu \mathrm{l}$ of DNA $(10 \mathrm{ng} / \mu \mathrm{l})$. An ABI PRISM ${ }^{\bullet} 7500$ equipment (Applied Biosystems, USA) was used to amplify and detect the reaction products, using the following conditions: $50^{\circ} \mathrm{C}$ for $2 \mathrm{~min}, 95^{\circ} \mathrm{C}$ for $10 \mathrm{~min}$, followed by $40 \mathrm{cycles}$ of $94^{\circ} \mathrm{C}$ for $15 \mathrm{~s}$ and $60^{\circ} \mathrm{C}$ for $1 \mathrm{~min}$ (Baigent et al., 2005).

Standards for qPCR. Chicken embryo fibroblast (CEF) cell cultures were prepared from 10-day-old chicken embryos. CEF cell cultures were infected at $80 \%$ confluence with viruses belonging to each serotype of the conventional strains used in the Pirbright Institute (MeHV-1: HVT strain Fc126, GaHV-3: strain SB1, GaHV-2: strain CVI988/Rispens). When cytopathic effect was evident under the microscope, infected CEF cells were harvested using a $0.05 \%$ Trypsin/Versene solution and total DNA was extracted using a commercial DNeasy blood and tissue kit (Qiagen). DNA was extracted using the manufacturer's recommendations from each infected (MeHV-1, GaHV-3, or GaHV-2) and uninfected cell culture (control). Sets of serial dilutions $\left(10^{-1}\right.$ to $\left.10^{-7}\right)$ were prepared from each extracted DNA and calibrated against plasmids of known copy number to determine the number of virus genome copies in each serial dilution. The sets of serial dilutions were used to generate standard curves in qPCR for conversion of CT values to MDV genome copy number. Data were analyzed as described previously (Baigent et al., 2005).

Analysis of pathotypes by PCR. The nucleotide sequence of the $B a m H I-H$ and BamHI-D regions of the virus genome was used to differentiate pathogenic strains from non-pathogenic isolates in GaHV-2, according to 132 bp repeats copy numbers according to Becker (Becker et al., 1992). The most pathogenic strains tend to have only one or two repeats of the $132 \mathrm{bp}$ band, while the mild strains typically have 6 to 7 repeats (Doosti and Golshan, 2011). When the GaHV-2 genome showed two 132 bp repeats, the prim- ers had amplified a segment of 434 bp (BamHI-H and BamHI-D primers, Table 1). PCR conditions were similar to those described earlier for GaHV-2, using 35 cycles of $94^{\circ} \mathrm{C}$ for $1.5 \mathrm{~min}, 55^{\circ} \mathrm{C}$ for 1 min, and $72^{\circ} \mathrm{C}$ for 2 min (Davidson et al., 2002).

Sequencing and phylogenetic analysis. The Meq gene PCR products were purified from the gel using the QIAquick gel extraction kit (Qiagen) following the manufacturer's recommendations. The product, at a concentration of $1 \mathrm{ng} / \mu \mathrm{l}$ per $100 \mathrm{bp}$, was stored at $4^{\circ} \mathrm{C}$ until sequencing. Sequencing oligonucleotides were designed to amplify the full length $\mathrm{Meq}$ gene. Sequence data were assembled and edited over a total length of $1020 \mathrm{bp}$ using the SeqMan program (DNA Star Laser gene software package, USA). DNA sequence Acc. Nos. for Meq-encoding genes are summarized in Table 5. Nucleotide BLAST was used to explore sequence similarity of MDV strain to some of the available sequences of Meq in the NCBI nucleotide databases. Nucleotide and deduced amino acid alignments of the 25 full-length Meq gene sequences, along with Colombian strains, were performed with MEGA 6 using the Muscle algorithm, and uncorrected ( $\mathrm{p}$ ) distances for nucleotide and amino acid sequences were calculated. A phylogenetic tree was generated using the neighbor-joining $(\mathrm{N}-\mathrm{J})$ method, with 1000 replicates. The MDV reference sequences were retrieved from the GenBank database, and their accession numbers are listed in Figure 3.

Virus isolation. The spleens preserved at $-80^{\circ} \mathrm{C}$, were finely minced with a blade and suspended in $5 \mathrm{ml}$ of DMEM (powder, high glucose, Gibco, USA) supplemented with $2 \%$ antibioticantimycotic solution (Antibiotic-Antimycotic 100x, Gibco). After that, the tissue was macerated and passed through a $40 \mu \mathrm{m}$ cell sieve into a $50 \mathrm{ml}$ falcon tube using a $10 \mathrm{ml}$ syringe. The cell suspension was subsequently layered onto a Ficoll gradient (Ficoll Paque Premium, GE Health Care, USA) and centrifuged at 2,100 $\mathrm{rpm}$ for $15 \mathrm{~min}$ at $4^{\circ} \mathrm{C}$. The interface containing the splenocytes was aspirated and washed in DMEM supplemented with $2 \%$ antibiotic-antimycotic solution. The splenocytes were inoculated onto primary CEF cultures that were $80 \%$ confluent. Inoculum dose was $1 \times 10^{6}$ leucocytes per well ( 6 well plates). The culture system was incubated at $38.5^{\circ} \mathrm{C}$ with $5 \% \mathrm{CO}_{2}$ and observed daily using an inverted light microscope (Olympus CKX31) to establish the presence of cytopathic effect on the cells (CPE). Once the CPE was observed, CEF cells were harvested, DNA was extracted, and a PCR was performed for GaHV-2 (Table 1, primers GaHV-2 gene $\mathrm{Meq})$ to confirm the presence of the virus.

\section{Results}

In total, we analyzed 96 DNA samples (72 from blood and 24 from pooled feathers) from 72 young layers from 4 different commercial egg producing farms, and 11 samples (10 from blood, and 1 from pooled feathers) from 10 backyard layers from nearby farms in the province of Antioquia, Colombia. The results are presented by age category. 
(a)

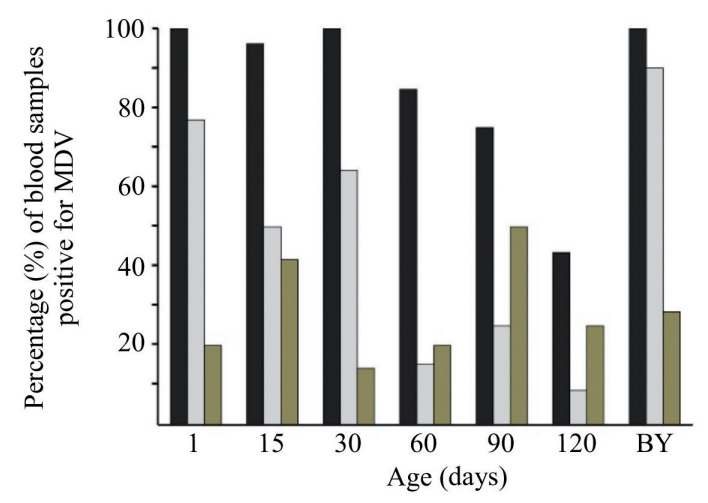

(c)

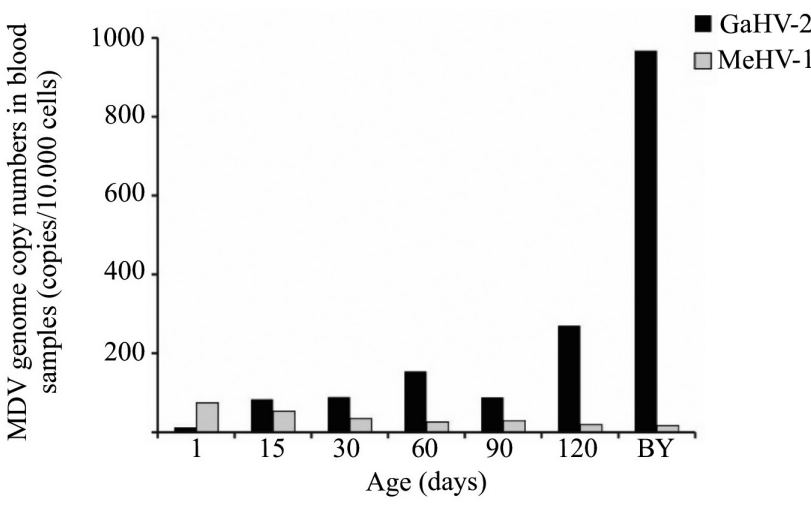

The three serotypes of $M D V$ were detected in whole blood and feathers of young layers from commercial egg producing farms of Antioquia

Using conventional PCR on blood samples for the detection of MeHV-1, an overall downward trend in positive number of birds was observed with increasing age (Fig. 1a). All birds $(100 \%, 12 / 12)$ were positive for MeHV-1 at day 1 ( $2-3$ days after vaccination) and $42 \%(5 / 12)$ remained positive by day 120 .

A similar downward trend was observed for GaHV-2, with $75 \%(9 / 12)$ and $8 \%(1 / 12)$ positive blood samples on day 1 and 120, respectively (Fig. 1a). By contrast, only $17 \%(2 / 12)$ and 25\% (3/12) of blood samples were positive for GaHV-3 on days 1 and 120, respectively. Although detection rate for the three serotypes was different amongst all age categories, MeHV-1 was the most prevalent serotype in every age category and farm studied. In unvaccinated backyard birds $100 \%(10 / 10)$ of blood samples were positive for MeHV-1, $90 \%$ (9/10) for GaHV-2 and 30\% (3/10) for GaHV-3 (Fig. 1a).

In pooled feather samples, MeHV-1 and GaHV-2 was detected in all ages in commercial and backyard chickens. (b)

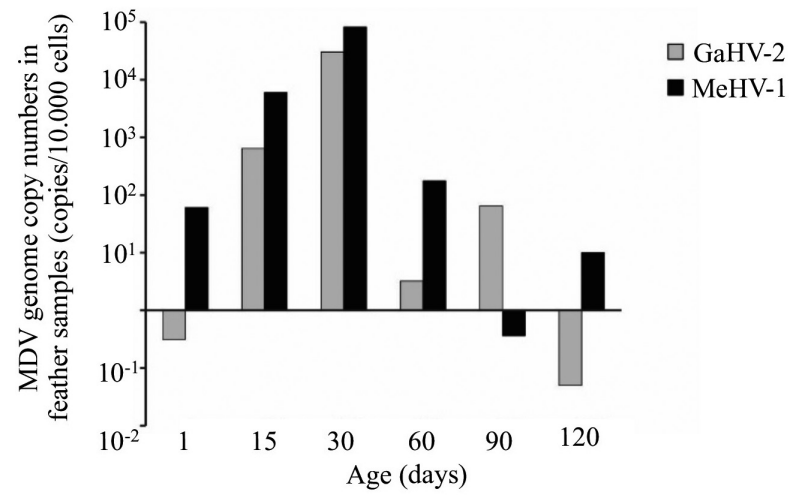

Fig. 1

Detection of MDV in blood and feather samples from layers vaccinated with FC126 HVT and CVI988-Rispens

Total DNA was extracted from blood and feathers in six different age groups of layer chickens and tested by standard PCR ((a) and (b)) and a duplex q-PCR reaction ((c) and (d)) to confirm presence of MDV genetic material. (a) The results are presented as total percentage of blood samples $(n=12$ per age) tested for MDV. Each bar represents the percentage of birds positive to GaHV-2, GaHV-3 and MeHV-1. (b) qPCR reaction and genome copy number per $10^{4}$ whole blood cells was calculated for GaHV-2 and MeHV-1 for every age category. Each bar represents the mean values for GaHV-2 and MeHV-1 expression. BY represents the mean values for backyard chickens. GaHV-2 = cut-off for q-PCR reaction $=0.2$; efficiency $=3.73$; cut-off for reference reaction $=0.2$; efficiency $=3.25 ; 18.6$ copies limit. MeHV-1 3 = cut-off for q-PCR reaction $=0.2$; efficiency $=3.80$; cut-off for reference reaction $=0.2$; efficiency $=3.2 ; 4$ copies limit. $(\mathbf{d}) \mathrm{qPCR}$ reaction and genome copy number per $10^{4}$ cells in pooled feather samples.

Both were present in all four pooled samples on days 15 and 90 (Fig. 1b). GaHV-3 was only detected in commercial farms in about half of all the pooled samples across all age categories (data not shown).

Real time qPCR was used to quantify the MDV serotypes. The limits of the qPCR detection for GaHV-2, GaHV-3 and MeHV-1 were 18.6, 9.4 and 4 copies of genome respectively, and data were normalized against the reference gene (Ovotransferrin), whereby the limit of detection was 14.8 copies per 10,000 cells. When the data were converted into genome copy numbers per 10,000 cells, the sample with the lowest level of GaHV-2 virus had 0.3 copies and the sample with the highest level of virus had 30.297 copies per 10,000 cells, both in pooled feather samples (Table 3). About 95\% of blood samples tested were positive by qPCR for GaHV-2. Figure 1c shows that the GaHV-2 was found at low levels on day one, but increased by day 15 and 30, reaching the maximum values at 60 and 120 days. By contrast, MeHV-1 showed highest values in blood on day 1 and decreased over time. For GaHV-3, blood samples were negative for all ages; however, pooled feather samples were positive with a minimum of 0.04 and a maximum of 166 copies (Table 3). 
(a)

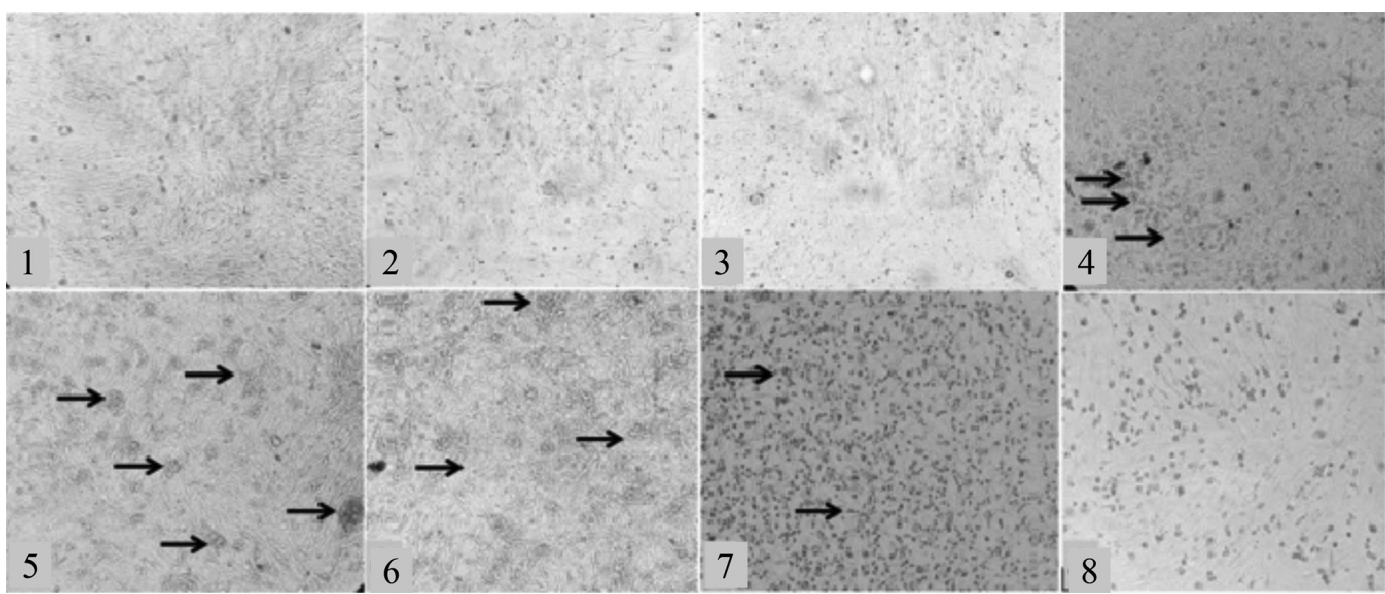

(b)

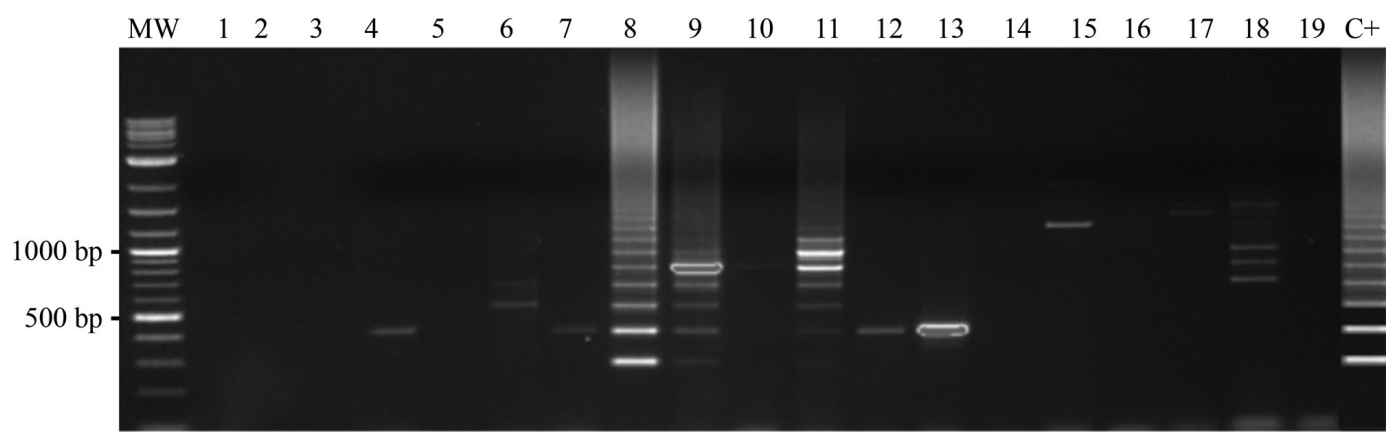

Fig. 2

In vitro replication and characterization of a Colombian wild-type pathogenic MDV strain

(a) Series of panels showing representative CEF monolayers inoculated with splenocytes demonstrating progressive formation of large and rounded plaques characteristic of GaHV-2 (black arrow) infection. Panel 1: 0 h, control. Panel 2: 24 h. Panel 3: 48 h. Panel 4: 72 h. Panel 5: 96 h. Panel 6: 100 h. Panel 7: first passage showing larger plaque formations. Panel 8: $24 \mathrm{~h}$ after first passage. (b) Amplification products of $132 \mathrm{bp}$ PCR. Positive control Rispens strain (8 repetitions). 1\% agarose gel. Horizontal axis: MW: molecular weight marker. C +: positive control strain Rispens (8 bands). 1-18: blood samples: 1 (day 1), 2 (day 1), 3 (day 1), 4 (day 120), 5 (day 1), 6 (day 1), 7 (day 15), 8 (day 30), 9 (day 60), 10 (day 120 ), 11 (day 120 ), 12 (day 120 ), 13 (day 1), 14 (day 15), 15 (day 30), 16 (day 60), 17 (day 90), 18 (day 120), 19 (negative control).

Because this serotype was not included in the vaccines, it represents a wild-field infection. In feathers, it was evident that the peak level for viral presence and shedding occurred on day 30, with MeHV-1 having the highest level of virus excreted into the environment (Fig. 1b). Blood samples obtained from backyard birds were shedding considerably more GaHV-2 than commercial birds, with a value of 966 copies of genome compared to 269 copies on day 120 in commercial chickens (Table 3 ). These birds are allowed to roam the countryside, foraging around neighboring commercial farms and could be a major biosecurity threat. In addition, $84.6 \%$ of feather samples were positive for GaHV-3 with a minimum of 0.33 and a maximum of 166.9 copies. On days 15, 60, 90 and 120, samples were negative (Table 3). Only feathers from day $1(0.33)$ and 30 (166.9) were found positive for GaHV-3, whereas all blood samples in all ages were negative. However, these findings are indicative of wild-field infection because neither farm uses a GaHV-3 vaccine. All
Table 3. Average MDV quantification of blood and feather samples Results are expressed as number of copies of viral genome per 10,000 cells

\begin{tabular}{ccccccc}
\hline \multirow{2}{*}{$\begin{array}{c}\text { Age } \\
\text { (days) }\end{array}$} & \multicolumn{2}{c}{ Whole blood samples (72) } & & \multicolumn{3}{c}{ Feather samples (16 pools) } \\
\cline { 2 - 3 } \cline { 5 - 7 } & GaHV-2 & MeHV-1 & & GaHV-2 & GaHV-3 & MeHV-1 \\
\hline 1 & 13.03564 & 75.37964 & & 0.31 & 0.33 & 60.71 \\
15 & 83.48471 & 53.64669 & & 645.15 & 0 & 5982.61 \\
30 & 89.64499 & 34.8987 & 30.297 .88 & 166.93 & 82.033 .30 \\
60 & 153.9335 & 26.38574 & & 3.23 & 0 & 176.57 \\
90 & 89.27613 & 30.24934 & & 65.05 & 0 & 0.36 \\
120 & 269.8948 & 19.60412 & 0.04 & 0 & 10.01 \\
BY & 966.6515 & 16.8079 & & 0 & 0.33 & 0 \\
\hline
\end{tabular}

Serotype 1 = cut-off for reaction of viral gene $=0.2$; efficiency $=3.73$; cut-off for reference reaction $=0.2$; efficiency: $3.25 ; 18.6$ copies limit. Serotype 3 $=$ cut-off for reaction of viral gene $=0.2$; efficiency $=3.80$; cut-off for reference reaction $=0.2$; efficiency: $3.2 ; 4$ copies limit. BY: Backyard chickens (up to 3 months old). In whole blood samples, the GaHV-3 was negative in all the ages. Whole blood samples analyzed 12 per age. Feather samples 4 pools per age. 
pooled feather samples were positive for MeHV-1, ranging from 0.3 to 82,033 copies. A significant increase in levels of MeHV-1 was observed at day 15 , following a similar trend to that observed for GaHV-2.

Viral loads increased in pooled feather samples to a maximum of 30.297 and 82.033 copies $x 10^{5}$ feather cells at day 30 for GaHV-2 and MeHV-1, respectively. They then decreased, and by day 120 were undetected for GaHV-2 and there were only 10.01 copies x $10^{5}$ feather cells for MeHV-1. Unlike in feather samples, levels of GaHV-2 in blood steadily increased over time, with low levels (13 copies) on day 1 and reaching its highest peak with 269 copies $x 10^{5}$ blood cells on day 120 .

The number of bands found in the PCR BamH segment suggest that several wild GaHV-2 strains were circulating in the farms

Different numbers of bands were observed after PCR amplification of the BamH segment in 70\% (25/35) of the pooled feather samples. Of those positive, $8 / 25$ samples had one band, 8/25 contained eight bands, and the remaining

Table 4. Percentage of strains with identity for some sequenced samples

\begin{tabular}{llcl}
\hline $\begin{array}{l}\text { Farm code and } \\
\text { sequence name }\end{array}$ & Strain & $\begin{array}{l}\text { Identification } \\
\text { of strain (year) }\end{array}$ & $\begin{array}{l}\text { Acc. No. } \\
\text { (\% identity) }\end{array}$ \\
\hline D2P (UDEACO 02/14) & RB1B & 2010 & HM488349 (99\%) \\
D3P (UDEACO 02/14) & RB1B & 2010 & HM488349 (99\%) \\
DUST (UDEACO 03/14) & CU-2 & 2007 & EU499381 (100\%) \\
& 3004 & 2007 & EU032468 (99\%) \\
M3P (UDEACO 08/14) & RB1B & 2010 & HM488349 (99\%) \\
\hline
\end{tabular}

samples (9/25) revealed two bands of 1000 and $1134 \mathrm{bp}$ which are indicative of multiple insertion repeats of the target fragment (8 repeats) (Fig. 2b). Whereas only one band was observed on days 1 and 15 in feather samples, there were eight bands of 132 repeats on day 30 . These results suggest that more than one strain of serotype 1 (GaHV-2), with attenuated to mild virulence characteristics, were circulating in the farms. If there is a highly virulent GaHV-2 strain, 1 or 2 repetitions of a size of $434 \mathrm{bp}$ are found in the gel analysis. Figure $2 \mathrm{~b}$ shows the different band patterns of the feather samples at different ages.

Mutations in the Meq gene sequence suggests mild and virulent $\mathrm{GaHV}-2$ strains

The Meq sequence from the GaHV-2 isolate showed amino acid changes associated with vaccine and virulent strains (Table 5). A BLAST search for circulating strains and their respective sequences (http://blast.ncbi.nlm.nih. gov/Blast) revealed a 99\% identity with American field and vaccine strains (Table 4).

Therefore, the amino acid alignment of the Colombian Meq gene to that of known sequences from various virulent and vaccine strains suggested that the Colombian MDV strains isolated belong to virulent and mild GaHV-2 strains. Phylogenetic classification resulted in clustering of the Colombian strain with US field and vaccine strains (Fig. 3).

Viral isolation generated the characteristic cytopathic effect of $\mathrm{GaHV}-2$ on $\mathrm{CEF}$

The CPE, characterized by formation of round refractive cells with some areas of cell detachment, was observed at 72 $\mathrm{h}$ post inoculation with the splenocytes. This is in line with

Table 5. Sequence alignment of the deduced amino acid sequence of Meq protein

\begin{tabular}{|c|c|c|c|c|c|c|c|c|c|c|c|c|c|c|c|c|c|}
\hline Strain & Type & Code & 71 & 77 & 80 & 93 & 115 & 119 & 153 & 176 & 180 & $217 / 276$ & 233 & 258 & $277 / 336$ & $283 / 342$ & $320 / 379$ \\
\hline $\mathrm{cu}-2$ & mMDV & AY362708 & $S$ & $\mathrm{E}$ & $\mathrm{D}$ & $\mathrm{Q}$ & $\mathrm{V}$ & $\mathrm{C}$ & $\mathrm{P}$ & $\mathrm{P}$ & $\mathrm{T}$ & $\mathrm{P}$ & $\mathrm{P}$ & $\mathrm{L}$ & $\mathrm{L}$ & A & I \\
\hline 567 & vMDV & AY362709 & $\mathrm{A}$ & E & $\mathrm{Y}$ & $\mathrm{Q}$ & $\mathrm{V}$ & $\mathrm{R}$ & $\mathrm{P}$ & $\mathrm{P}$ & $\mathrm{T}$ & $\mathrm{A}$ & $\mathrm{P}$ & $\mathrm{L}$ & $\mathrm{L}$ & $\mathrm{A}$ & I \\
\hline 627 & vMDV & AY362713 & $\mathrm{A}$ & $\mathrm{E}$ & $\mathrm{Y}$ & $\mathrm{Q}$ & V & $\mathrm{R}$ & $\mathrm{P}$ & $\mathrm{P}$ & $\mathrm{T}$ & A & $\mathrm{P}$ & $\mathrm{L}$ & $\mathrm{L}$ & A & I \\
\hline bc-1 & vMDV & AY362707 & S & $\mathrm{A}$ & $\mathrm{D}$ & $\mathrm{Q}$ & A & $\mathrm{C}$ & $\mathrm{P}$ & $\mathrm{P}$ & $\mathrm{T}$ & $\mathrm{P}$ & $\mathrm{P}$ & $\mathrm{L}$ & $\mathrm{L}$ & A & I \\
\hline JM & vMDV & AY243331 & S & $\mathrm{A}$ & $\mathrm{D}$ & $\mathrm{R}$ & A & $\mathrm{C}$ & $\mathrm{P}$ & $\mathrm{P}$ & $\mathrm{T}$ & $\mathrm{P}$ & $\mathrm{P}$ & $\mathrm{L}$ & $\mathrm{L}$ & A & I \\
\hline 686 & $\mathrm{vv}+\mathrm{MDV}$ & AY362727 & A & $\mathrm{K}$ & $\mathrm{D}$ & $\mathrm{Q}$ & $\mathrm{V}$ & $\mathrm{R}$ & Q & A & A & A & $\mathrm{P}$ & $\mathrm{L}$ & $\mathrm{P}$ & A & I \\
\hline RL & $\mathrm{vv}+\mathrm{MDV}$ & AY362720 & $\mathrm{A}$ & $\mathrm{K}$ & $\mathrm{D}$ & $\mathrm{Q}$ & V & $\mathrm{R}$ & $\mathrm{Q}$ & A & A & A & $\mathrm{P}$ & $\mathrm{L}$ & $\mathrm{L}$ & A & I \\
\hline TK & $\mathrm{vv}+\mathrm{MDV}$ & AY362721 & A & $\mathrm{K}$ & $\mathrm{D}$ & $\mathrm{Q}$ & $\mathrm{V}$ & $\mathrm{R}$ & Q & A & A & A & $\mathrm{P}$ & $\mathrm{L}$ & $\mathrm{L}$ & A & I \\
\hline RB1B & vvMDV & AY243332 & A & K & $\mathrm{D}$ & $\mathrm{Q}$ & $\mathrm{V}$ & $\mathrm{C}$ & $\mathrm{P}$ & $\mathrm{P}$ & $\mathrm{T}$ & $\mathrm{P}$ & $\mathrm{P}$ & $\mathrm{L}$ & $\mathrm{L}$ & $\mathrm{A}$ & I \\
\hline $\mathrm{D} 2 \mathrm{P}$ & & UDEACO 02/14 & $A$ & $E$ & $D$ & $Q$ & $V$ & C & $P$ & $P$ & $T$ & $P$ & $P$ & $L$ & $\mathrm{~L}$ & $\mathrm{~A}$ & I \\
\hline Dust & & UDEACO 03/14 & $S$ & $E$ & $D$ & $Q$ & $V$ & C & $P$ & $P$ & $T$ & $P$ & $P$ & $L$ & $L$ & $A$ & $I$ \\
\hline M3P & & UDEACO 08/14 & $S$ & $E$ & $D$ & $Q$ & $V$ & C & $P$ & $P$ & $T$ & $P$ & $P$ & $L$ & $L$ & $A$ & $I$ \\
\hline
\end{tabular}

Exchange positions of amino acids that are associated with virulence. Meq protein, amino acids 1 to 400 . The strains of the study show a similar pattern for mMDV and vMDV vaccine strains. 


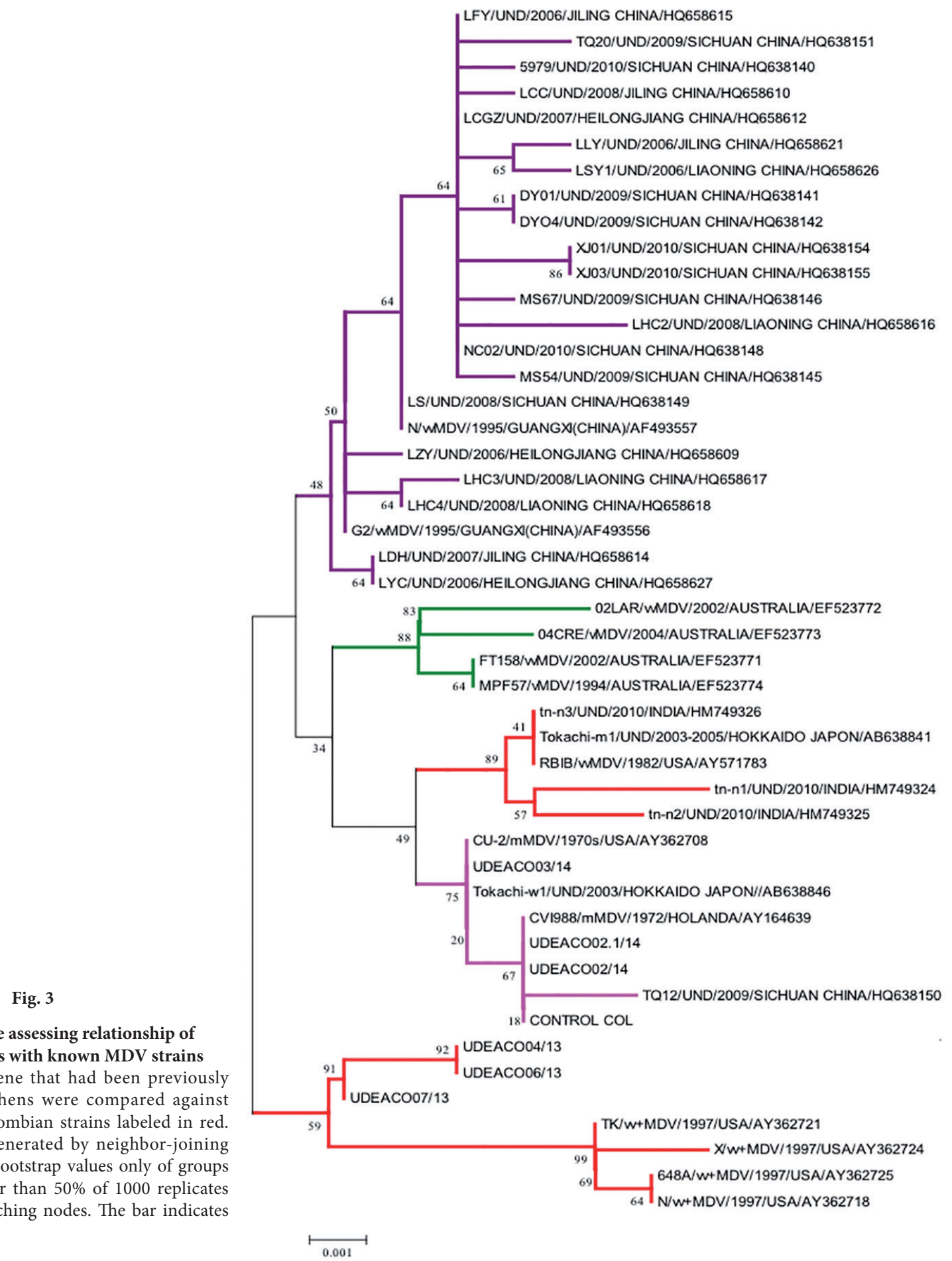

Phylogenetic tree assessing relationship of Colombian strains with known MDV strains Sequences of $\mathrm{Meq}$ gene that had been previously sequenced in layer hens were compared agains the UDEACO $=$ Colombian strains labeled in red. Dendograms were generated by neighbor-joining method. Percentage bootstrap values only of group and subgroups higher than $50 \%$ of 1000 replicates are indicated at branching nodes. The bar indicates sequence divergence.

previously documented evidence on MDV CPE formation. On the fifth day, the cells were harvested and DNA extracted for conventional PCR, which confirmed that samples were positive for the Meq gene, proving the isolation of GaHV-2 (Fig. 2a).

\section{Discussion}

Marek's disease has been underestimated in Colombia and, as a consequence, there is a lack of information in the country. A presumptive diagnosis of Marek's disease has been 
traditionally based on histopathology with no molecular confirmation of MDV presence until now. Neither the pathogenesis of MDV nor its infection dynamics have been studied in Colombian poultry before. Furthermore, the vaccine strains have not even been evaluated for their efficacy against field strains, so their use might have contributed to selective pressure for more pathogenic strains resulting in a break of the protection conferred by current vaccines (Gimeno, 2008). This could partially explain some recent outbreaks of high mortalities caused by vv+ GaHV-2 strains reported in 2017 (Lopez-Osorio et al., 2017). However, the molecular and pathological characteristics need to be established.

In order to contribute to that knowledge, we performed PCR and qPCR as described before (Markowski-Grimsrud et al., 2002; Becker et al., 1992, 1993; Baigent et al., 2005; Wajid et al., 2013; Renz et al., 2006) to detect the presence of the MDV in the first place.

It is known that the HVT vaccine (naturally avirulent: MeHV-1 strain FC126) is highly effective in preventing Marek's disease, but although the virus has long persistence (Burmester et al., 1972) it will not prevent infection with other serotypes (Burmester et al., 1972; Purchase and Okazaki, 1971; Okazaki et al., 1970). When analyzed, blood samples from all farms were positive for serotypes 1 and 3 (GaHV-2 and MeHV-1 by conventional PCR), which was expected because the chickens had been vaccinated at the hatchery with these serotypes at 1 day of age. There were some samples positive for serotype 2 (GaHV-3), which suggests a natural infection with this non-virulent field strain. Based on that, and considering that co-infection with vaccine and field virus strains can lead to the evolution of MDV and generate more virulent pathotypes (Gandon et al., 2001), this mechanism is suspected to be part of the MDV evolution (Davidson and Shkoda, 2005; Atkins, 2010) and could help to explain the results of this study. This interaction may affect the virus kinetics, reducing the pathogenic MDV load in lymphocytes (Baigent et al., 2011) and feather follicles which is consistent with the findings in this study with respect to the vaccine serotypes (GaHV-2 and MeHV-1) and the field serotype (GaHV-3). It has also been observed that challenge with GaHV-2 at 5 days after vaccination, increases viral shedding in feathers, as compared with non-challenged birds (Islam et al., 2014), which contrasts with Haq et al. (2012), who did not find this difference. Islam et al. (2014) found that the co-infection with different serotypes leads to a competition which therefore suppresses the replication of the two viruses in blood and particularly in feathers. The virus behavior found in this study suggests that field strains could be contributing to abnormal peaks of positivity found at different time-points in blood and in feathers. According to this, the DNA of the three serotypes of MDV may be found from 5 to 7 days after infection and could predict the presence of signs of MD as reported previously (Islam et al., 2013). Flint et al. (2004) described the feather follicle as a tissue that has poor immune response against viral replication, explaining why viruses may survive longer at this location. Other authors have found host response against MDV in feather pulp at 4 days post-infection, which coincides with increasing transcription of IFN- $\gamma$ and infiltration with CD4+ and CD8+ cells in the tissue (AbdulCareem et al., 2008). We found all the three serotypes at all tested ages in feathers, which is similar to that observed by other authors in which the excretion of MeHV-1 in feathers of HVT vaccinated birds was low but prolonged (until 45 days of age), while the GaHV-2 (field strain) excretion was higher than $\mathrm{MeHV}-1$, but at lower levels than would be expected in challenged non-vaccinated birds (Levy et al., 2007). Fourteen days post-infection the levels of GaHV-2 had 100 copies in blood, while in feathers it was much higher $(12,000)$ (Baigent et al., 2005; Davidson and Borenshtain, 2003) which was consistent with the findings in this study, in which we had levels of more than 6,000 copies after 15 days in feathers, and less than 100 copies in blood. CVI988 vaccine strain shows similar behavior in feathers, with values of more than 1,000 copies after 11 days post inoculation (Baigent et al., 2011), and in unvaccinated birds challenged with strain RB-1B, more than 100,000 copies of RB-1B have been observed.

Infection only with GaHV-2 has shown that viral replication occurs mainly in the first days post-infection in both blood and feathers (Baigent and Davison, 2004), and it is effectively transmitted to birds that have not been vaccinated (Islam et al., 2014). In this research we found a peak for GaHV-2 at 15 and 90 days, contrary to what Baigent et al. found in SPF birds under controlled conditions (Baigent et al., 2005), which had a positive peak at 14 days and then decreased slowly. This difference could be explained by the fact that those birds were not challenged by field virus, while our birds probably had contact with field strains. Nevertheless, our results are similar to Levy et al. (1991) who found high levels of MDV in feathers in vaccinated birds after challenge at 10 days post vaccination, with a peak 25 days after the challenge. This suggests that the birds in our study had an infection with a field strain approximately at 65 days of age, resulting in increasing levels of GaHV-2 at 90 days of age.

It is known that the viral load in the feathers is a good indicator of MDV load in the lymphoid organs (Cho et al., 1998), so measuring viral load in feathers may be used as a monitoring system of vaccination; and it could also be used for diagnostics if the viral load is high, leading to optimal time of revaccination, and even to evaluate the amount of virus being released into the environment (Baigent et al., 2013). The diagnostic value of MDV genome detection in the feathers in commercial poultry is evident as it has previously been shown (Handberg et al., 2001; Islam et al., 2014; Davidson and Shkoda, 2005). Feather follicle epithelium is the site in which the replication and release of cell-free MDV occurs and is expelled in to the environment (Calnek et al., 
1970), and it can be found after 10 days post-infection; also, similar to what we found, other authors report the presence of MDV in feathers after 2 (Davison and Nair, 2004) or 3 days post-infection (Baigent et al., 2013). It is important to mention that in our study birds were positive for MDV presence in feathers as early as 1 day (2-3 days old birds).

The kinetics of viral replication and excretion differ between the vaccine and field virus strains. On the first day, GaHV-2 genome was found in low concentration (1.4 copies) levels, but it increased at day 15, 30 and 60. After 90 days the viral load decreased but rose again, reaching a peak at 120 days. This behavior is consistent with the replication cycle of the field virus, which presents slow declination (Baigent and Davison, 2004). It has been found that the vaccine strain exhibits a peak in blood at 7 (Renz et al., 2006) or 14 days (Baigent et al., 2005), with a slow decrease in subsequent days, while the field strain continues increasing up to 35 days post-infection (Renz et al., 2006). Also, this study found that the positivity of MeHV-1 shows a peak at 30 days in feathers and then decreased.

In relation to investigating the pathotype with the conventional PCR, we amplified the fragments of BamHI nucleotide sequences. It has been reported that fragments of BamHI-H and BamHI-D nucleotide sequences of the $\mathrm{MDV}$ genome are altered by in vitro passages suggesting that these genomic changes are associated with attenuation of oncogenic strains (Kalyani et al., 2011). In the BamHI PCR we found about eight bands in some of the samples (compatible with attenuated strains), while in others only one or two bands, suggesting the infection with more than one strain with different levels of attenuation. It has been reported that the GaHV-2 has three bands of 132 bp repeats in the $\mathrm{L}$ terminal and internal fragment. Other authors found two bands in the fragment (Davidson et al., 2002), while Kanamori et al. (1986) reported the presence of two or three bands in the GaHV-2 genome. It has been reported that the virus tumorigenicity is associated with the number of repetitions of $132 \mathrm{bp}$ region, as this segment gives rise to an mRNA encoding protein family such as pp38 and a DNA fragment BamHI-H, which are associated with the state of cell transformation. The number of amplified $132 \mathrm{bp}$ repeats in GaHV-2 indicates the change in gene expression or pp38 additional genes (Becker et al., 1992; Kalyani et al., 2011).

Unfortunately, to correctly classify the strain by its pathotype, it is necessary to perform the in vivo test in SPF chickens to establish its virulence (Zhang et al., 2015). Because special biosecurity facilities which are required to isolate the SPF chickens were not available, the complete classification of the strains was not possible in this study. Nevertheless, the strains were classified according to the deduced amino acid sequence of the protein Meq. As a result of that, the predicted protein sequences showed similarity with vaccine and attenuated field strains (Chang et al., 2002; Zhang et al.,
2011). The MDV strains clustered in the phylogenetic analysis with group IV, with the attenuated type and having a high percentage identity with strains of the same continent, which is in agreement with previous studies showing that strains of different isolates tend to be grouped by geographical regions, showing a pattern by location (Zhang et al., 2011; Murata et al., 2013; Luo et al., 2013). Remarkably, this suggests the presence in both blood and feathers of vMDV, mMDV and vaccine strains circulating together in the farms, suggesting that birds are being challenged with field virus and may have also co-infection with other strains of attenuated and virulent character. Backyard birds also showed infection with three serotypes imposing a risk to commercial poultry because they can serve as a source of infection of more virulent virus that can lead to outbreaks on farms during the production. According to the results shown here it can be concluded that MDV is circulating in the farms from northern and eastern Antioquia, and that there is more than one serotype and different pathotypes present in the birds representing a threat to the poultry industry. It is necessary to continue studying MDV and to establish the pathotype characteristics of the viruses circulating not only in commercial but also in backyard chickens. It is also recommended to analyze the real impact of MDV infection alone or in combination with other viral and bacterial agents affecting the birds in Colombia.

Acknowledgments. We thank to the Pirbright Institute, U.K. In addition to the laboratory Bioara SA for providing the SPF eggs for cell cultures. Centauro Research Group and Universidad Nacional de Colombia, Bogota. Funding: COLCIENCIAS - University of Antioquia (Code 111552128321; Contract 0155-2012).

\section{References}

Abdul-Careem MF, Huntera BD, Nagy E, Read LR, Sanei B, Spencer JL, Sharif F (2006): Development of a real-time PCR assay using SYBR Green chemistry for monitoring Marek's disease virus genome load in feather tips. J. Virol. Methods 133, 34-40. https://doi.org/10.1016/j. jviromet.2005.10.018

Abdul-Careem MF, Hunter BD, Sarson AJ, Parvizi P, Haghighi HR, Read L, Heidari M, Sharif S (2008): Host responses are induced in feathers of chickens infected with Marek's disease virus. Virology 370, 323-332. https://doi. org/10.1016/j.virol.2007.09.013

Afonso CL, Tulman ER, Lu Z, Zsak L, Rock DL, Kutish GF (2001): The genome of turkey herpesvirus. J. Virol. 75, 971-978. https://doi.org/10.1128/JVI.75.2.971-978.2001

Atkins KE (2010): Epidemiology and evolution of Marek's Disease virus. Available at: http://hdl.handle.net/1842/4617.

Bagust TJ (2008): Salud de las aves de corral y control de enfermedades en los países en desarrollo. Revisión del desarrollo avícola. Available at: http://www.fao.org/docrep/016/ al729s/al729s00.pdf. 
Baigent S, Davison F (2004): Marek's disease virus: biology and life cycle. In Davidson, F, Nair V (Eds.): Marek disease virus: An Evolving Problem. London : Elsevier Academic Press, pp. 212. https://doi.org/10.1016/B978-012088379$\underline{0 / 50010-4}$

Baigent SJ, Petherbridge LJ, Howes K, Smith LP, Currie RJ, Nair VK (2005): Absolute quantitation of Marek's disease virus genome copy number in chicken feather and lymphocyte samples using real-time PCR. J. Virol. Methods 123, 53-64. https://doi.org/10.1016/j.jviromet.2004.08.019

Baigent SJ, Smith LP, Petherbridge LJ, Nair VK (2011): Differential quantification of cloned CVI988 vaccine strain and virulent RB-1B strain of Marek's disease viruses in chicken tissues, using real-time PCR. Res. Vet. Sci. 91, 167-174. https://doi.org/10.1016/j.rvsc.2010.08.002

Baigent SJ, Kgosana L, Gamawa A, Smith LP, Read AF, Nair V (2013): Relationship between levels of very virulent MDV in poultry dust and in feather tips from vaccinated chickens. Avian Dis. 57, 440-447. https://doi. org/10.1637/10356-091012-Reg.1

Baigent SJ, Nair VK, Le Galludec H. (2016). Real-time PCR for differential quantification of CVI988 vaccine virus and virulent strains of Marek's disease virus. J. Virol. Methods 233, 23-36. https://doi.org/10.1016/j.jviromet.2016.03.002

Becker Y, Tabor E, Asher Y, Davidson I, Malkinson M, Witter RL (1993): PCR detection of amplified 132 bp repeats in Marek's disease virus type 1 (MDV-1) DNA can serve as an indicator for critical genomic rearrangement leading to the attenuation of virus virulence. Virus Genes 7 , 277-287. https://doi.org/10.1007/BF01702588

Becker Y, Asher Y, Tabor E, Davidson I, Malkinson M, Weisman Y (1992): Polymerase chain reaction for differentiation between pathogenic and non-pathogenic serotype 1 Marek's disease viruses (MDV) and vaccine viruses of MDV-serotypes 2 and 3. J. Virol. Methods 40, 307-322. https://doi.org/10.1016/0166-0934(92)90089-V

Bello N, Francino O, Sanchez A (2001): Isolation of genomic DNA from feathers. J Vet Diagn Invest. 13, 162-164. https:// doi.org/10.1177/104063870101300212

Burmester BR, Purchase HG, Okazaki W (1972): Long-term experiences with the herpesvirus of turkeys (HVT) as a vaccine against Marek's disease. Prog. Immunobiol. Stand. 5, 132-138.

Calnek BW, Adldinger HK, Kahn DE (1970): Feather follicle epithelium: a source of enveloped and infectious cell-free herpesvirus from Marek's disease. Avian Dis. 14, 219-233. https://doi.org/10.2307/1588466

Chang KS, Ohashi K, Onuma M (2002): Diversity (polymorphism) of the Meq gene in the attenuated Marek's disease virus (MDV) serotype 1 and MDV-transformed cell lines. J. Vet. Med. Sci. 64, 1097-1101. https://doi.org/10.1292/ jvms.64.1097

Cho KO, Park NY, Endoh D, Ohashi K, Sugimoto C, Itakura C, Onuma M (1998): Cytology of feather pulp lesions from Marek's disease (MD) virus-infected chickens and its application for diagnosis and prediction of MD. J. Vet. Med. Sci. 60, 843-847. https://doi.org/10.1292/jvms.60.843

Davidson I, Borenshtain R (2003): Novel applications of feather tip extracts from MDV-infected chickens; diagnosis of commercial broilers, whole genome separation by PFGE and synchronic mucosal infection FEMS. Immunol. Med. Microbiol. 38, 199-203. https://doi.org/10.1016/S0928$\underline{8244(03) 00177-9}$

Davidson I, Borenshtain R (2002): The feather tips of commercial chickens are a favorable source of DNA for the amplification of Marek's disease virus and avian leukosis virus, subgroup J. Avian Pathol. 31, 237-240. https://doi. org/10.1080/03079450220136549

Davidson I, Borenshtain R, Weisman Y (2002): Molecular identification of the Marek's disease virus vaccine strain CVI988 in vaccinated chickens. J. Vet. Med. B Infect. Dis. Vet. Public Health 49, 83-87. https://doi.org/10.1046/j.14390450.2002.00512.x

Davidson I, Shkoda I (2005): The impact of feathers on the detection and study of DNA viral pathogens in commercial poultry. World's Poultry Sci. Assoc. J. 61, 407-417. https://doi. org/10.1079/WPS200552

Davison F, Nair V (2004): Marek's Disease: An evolving Problem. 1 st ed. Compton, UK, Elsevier B.V.

Doosti A, Golshan M (2011): Molecular study for detection of Marek' s disease virus (MDV) in southwest of Iran. Sci. Res. Essays 6, 2560-2563.

FAO (2006): Wild bird highly pathogenic avian influenza surveillance sample collection from healthy, sick and dead birds. Animal Production and Health. Food and Agriculture Organization of the United Nations Rome. http://www. fao.org/docrep/010/a0960e/a0960e00.htm

Flint SJ, Enquist LW, Racaniello VR, Skalka AM (2004): Principles of virology: molecular biology, pathogenesis, and control of animal viruses: patterns of infection. 2nd ed. Washington : American Society for Microbiology, 596-621.

Gandon S, Mackinnon MJ, Nee S, Read AF (2001): Imperfect vaccines and the evolution of pathogen virulence. Nature 414, 751-756. https://doi.org/10.1038/414751a

Gimeno IM (2008) Marek's disease vaccines: A solution for today but a worry for tomorrow?. Vaccine 26, C31-C41. https:// doi.org/10.1016/j.vaccine.2008.04.009

Handberg KJ, Nielsen OL, Jorgensen PH (2001): The use of serotype 1 - and serotype 3 -specific polymerase chain reaction for the detection of Marek's disease virus in chickens. Avian Pathol. 30, 243-249. https://doi. org/10.1080/03079450120054659

Haq K, Fear T, Ibraheem A, Abdul-Careem MF, Sharif S (2012): Influence of vaccination with CVI988/Rispens on load and replication of a very virulent Marek's disease virus strain in feathers of chickens. Avian Pathol. 41, 69-75. https://doi.org/10.1080/03079457.2011.640304

Islam A, Harrison B, Cheetham BF, Mahony TJ, Young PL, Walkden-Brown SW (2004): Differential amplification and quantitation of Marek's disease viruses using realtime polymerase chain reaction. J. Virol. Methods 119, 103-113. https://doi.org/10.1016/j.jviromet.2004.03.006

Islam A, Cheetham BF, Mahony TJ, Young PL, Walkden-Brown SW (2006): Absolute quantitation of Marek's disease virus and Herpesvirus of turkeys in chicken lymphocyte, feather tip and dust samples using real-time PCR. J. 
Virol. Methods 132, 127-134. https://doi.org/10.1016/j. jviromet.2005.10.009

Islam T, Walkden-Brown SW, Renz KG, Islam AF, Ralapanawe S (2014): Replication kinetics and shedding of very virulent Marek's disease virus and vaccinal Rispens/CVI988 virus during single and mixed infections varying in order and interval between infections. Vet. Microbiol. 173, 208-223. https://doi.org/10.1016/j.vetmic.2014.07.027

Islam T, Walkden Brown SW, Renz KG, Fakhrul Islam AF, Ralapanawe S (2013): Vaccination-challenge interval markedly influences protection provided by Rispens CVI988 vaccine against very virulent Marek's disease virus challenge. Avian Pathol. 42, 516-526. https://doi.org/10.1080/0307 9457.2013.841312

Jeltsch JMR (1987): Sequence of the chicken ovotransferrin gene. Nucl. Acids Res. 15, 7643-7645. https://doi.org/10.1093/ nar/15.18.7643

Jones D, Lee L, Liu JL, Kung HJ, Tillotson JK (1992): Marek disease virus encodes a basic-leucine zipper gene resembling the fos/jun oncogenes that is highly expressed in lymphoblastoid tumors. Proc. Natl. Acad. Sci. USA 89, 4042-4046. https://doi.org/10.1073/pnas.89.9.4042

Kanamori A, Nakajima K, Ikuta K, Ueda S, Kato S, Hirai K (1986): Copy number of tandem direct repeats within the inverted repeats of Marek's disease virus DNA. Biken J. 29, 83-89

Kalyani IH, Joshi CG, Jhala MK, Bhanderi BB, Purohit JH (2011): Characterization of 132 bp repeats BamH1-H region in pathogenic Marek's disease virus of poultry in Gujarat, India, using PCR and sequencing. Indian J. Virol. 22, 72-75. https://doi.org/10.1007/s13337-011-0031-6

Landman WJM, Verschuren SBE (2003). Titration of Marek's disease cell-associated vaccine virus (CVI 988) of reconstituted vaccine and vaccine ampoules from Dutch hatcheries. Avian Dis. 47, 1458-1465. https://doi.org/10.1637/7034

Lee SI, Takagi M, Ohashi K, Sugimoto C, Onuma M (2000): Difference in the Meq gene between oncogenic and attenuated strains Marek's disease virus serotype 1. J. Vet. Med. Sci. 62, 287-292. https://doi.org/10.1292/jvms.62.287

Levy H, Maray T, Davidson I, Malkinson M, Becker Y. (1991): Replication of Marek's disease virus in chicken feather tips containing vaccinal turkey herpesvirus DNA. Avian Pathol. 20, 35-44. https://doi.org/10.1080/03079459108418739

Lopez-Osorio S, Piedrahita D, Espinal-Restrepo MA, RamírezNieto GC, Nair V, Williams SM, Baigent S, Ventura-Polite C, Aranzazu-Taborda D, Chaparro-Gutiérrez JJ (2017): Molecular characterization of Marek' s disease virus in a poultry layer farm from Colombia. Poult. Sci. J. 96, 1598-1608. https://doi.org/10.3382/ps/pew464

López S, Piedrahita D, Ramírez-Nieto GC, Williams SM, AranzazuTaborda D, Chaparro-Gutiérrez JJ (2015): La inmunodepresión subclínica, un problema importante en los sistemas de producción avícola. Plumazos 51, 14-23.

Luo J, Teng M, Luo J, Wang XW, Ding K, Yu LL, Su JW, Chi JQ, Zhao P, Hu B, Zhang GP, Liu JX (2013): Molecular characteristics and evolutionary analysis of field Marek's disease virus prevalent in vaccinated chicken flocks in recent years in China. Virus Genes 47, 282-291. https:// doi.org/10.1007/s11262-013-0942-y
Markowski-Grimsrud CJ, Miller MM, Schat KA (2002): Development of strain-specific real-time PCR and RT-PCR assays for quantitation of chicken anemia virus. J. Virol. Methods 101, 135-147.https://doi.org/10.1016/S0166-0934(01)00430-X

Murata S, Hashiguchi T, Hayashi Y, Yamamoto Y, Matsuyama-Kato A, Takasaki S, Isezaki M, Onuma M, Konnai S, Ohashi K (2013): Characterization of Meq proteins from field isolates of Marek's disease virus in Japan. Infection, genetics and evolution. Infect. Genet. Evol. 16, 137-43. https://doi. org/10.1016/j.meegid.2012.12.032

Okazaki W, Purchase HG, Burmester BR (1970): Protection against Marek's disease by vaccination with a herpesvirus of turkeys. Avian Dis. 14, 413-429. https://doi. org/10.2307/1588488

Purchase HG, Okazaki W (1971): Effect of vaccination with herpesvirus of turkeys (HVT) on horizontal spread of Marek's disease herpesvirus. Avian Dis. 15, 391-397. https://doi. org/10.2307/1588710

Ralapanawe S, Renz KG, Burgess SK, Walkden-Brown SW (2016): Field studies of the detection, persistence and spread of the Rispens CVI988 vaccine virus and the extent of co-infection with Marek's disease virus. Aust. Vet. J. 94, 329-337. https://doi.org/10.1111/avj.12479

Ramírez C, Castro F, Gimeno I (2010): Evaluación de las técnicas de diagnóstico de la enfermedad de Marek. Rev. Colombiana Cienc. Anim. 3, 69-78.

Read AF, Baigent SJ, Powers C, Kgosana LB, Blackwell L, Smith LP, Kennedy DA, Walkden-Brown SW, Nair VK (2015): Imperfect vaccination can enhance the transmission of highly virulent pathogens. PLoS Biol. 13, e1002198. https://doi.org/10.1371/journal.pbio.1002198

Renz KG, Islam A, Cheetham BF, Walkden-Brown SW (2006): Absolute quantification using real-time polymerase chain reaction of Marek's disease virus serotype 2 in field dust samples, feather tips and spleens. J. Virol. Methods 135, 186-91. https://doi.org/10.1016/j.jviromet.2006.03.017

Sellers SM (2001): A quantitative analysis of Marek's disease virus in relation to host genetic resistance. University of Bristol, UK. Thesis.

Schat KA, Nair V (2013): Neoplastic diseases: Marek's disease. In Swayne D, Glisson JR, McDougald LR, Nolan LK, Suarez DL, Nair V (Eds.): Diseases of Poultry. 13th ed. WileyBlackwell, pp. 515-552.

Wajid SJ, Katz ME, Renz KG, Walkden-Brown SW (2013): Prevalence of Marek's disease virus in different chicken populations in Iraq and indicative virulence based on sequence variation in the $\{$ ecoRI-q\} (meq) gene. Avian Dis. 57, 562-568. https://doi.org/10.1637/10342-083112-Reg.1

Zhang Y, Li ZJ, Bao KY, Lv HC, Gao YL, Gao HL, Qi XL, Cui HY, Wang YQ, Ren XG, Wang XM, Liu CJ (2015): Pathogenic characteristics of Marek's disease virus field strains prevalent in China and the effectiveness of existing vaccines against them. Vet. Microbiol. 177, 62-68. https://doi. org/10.1016/j.vetmic.2014.12.020

Zhang, Y, Liu CJ, Zhang F, Shi W, Li J (2011): Sequence analysis of the Meq gene in the predominant Marek's disease virus strains isolated in China during 2006-2008. Virus Genes 43, 353-357. https://doi.org/10.1007/s11262-011-0645-1 